\title{
Large-scale remediation of oil-contaminated water using floating treatment wetlands
}

\author{
Muhammad Afzal ${ }^{1}$, Khadeeja Rehman ${ }^{1,2}$, Ghulam Shabir ${ }^{1}$, Razia Tahseen ${ }^{1}$, Amna ljaz ${ }^{3}$, Amer J. Hashmat ${ }^{1,4}$ and Hans Brix ${ }^{4}$
}

The contamination of water with hydrocarbons resulting from oil exploration and production highlights the need for efficient and environmentally friendly technology to mitigate this form of water pollution. Floating treatment wetlands are a sustainable approach for remediating contaminated water. In this large-scale study, we used four different plants, Phragmites australis, Typha domingensis, Leptochloa fusca, and Brachiaria mutica, to vegetate a floating mat with an area of $3058 \mathrm{~m}^{2}$ made from locally sourced materials. The floating treatment wetlands constructed in this manner were used to treat an oil-contaminated water stabilization pit resulting from oil and gas exploration activities in District Chakwal, Pakistan. The plants and the water in the pit were inoculated with a consortium of 10 different hydrocarbon-degrading bacteria. The application of floating treatment wetlands to the pit reduced chemical oxygen demand, biochemical oxygen demand, total dissolved solids, hydrocarbon content, and heavy metals by $97.4 \%, 98.9 \%, 82.4 \%, 99.1 \%$, and $80 \%$, respectively, within 18 months. All plants survived and showed growth, but maximum development and biomass production were exhibited by $P$. australis. Moreover, the bacteria used for inoculation were able to persist and show degradation activity in the water as well as in the rhizoplane, roots, and shoots of the plants. We conclude that floating treatment wetlands can be applied to oil-contaminated water stabilization pits for affordable and effective water treatment.

npj Clean Water (2019)2:3 ; doi:10.1038/s41545-018-0025-7

\section{INTRODUCTION}

Crude oil is the world's largest non-renewable energy resource, accounting for about $33 \%$ of the total consumed energy. Drilling and extraction processes for oil and gas generate huge volumes of oil-contaminated water, ${ }^{1,2}$ with the global generation of oilcontaminated water estimated to be 33.6 million barrels per day. ${ }^{3,4}$ The worldwide demand for oil is expected to keep rising in the coming years, which will potentially increase the generation of oil-contaminated water.

Crude oil consists of various proportions of different hydrocarbons, such as alkanes, aromatics, and polycyclic aromatic hydrocarbons, as well as non-hydrocarbons, including sulfur, nitrogen, and trace metals, particularly nickel, iron, and copper. ${ }^{5,6}$ Human exposure to hydrocarbons occurs primarily through skin contact and consumption of contaminated food and water. ${ }^{7}$ Some hydrocarbons are reported to be carcinogenic, neurotoxic, and genotoxic to humans and other organisms in the environment. ${ }^{8,9}$ In aquatic organisms, crude oil causes DNA damage, defects in cardiac function, and oxidative stress. ${ }^{10-12}$ This, in turn, reduces the abundance and diversity of fish, consequently disrupting ecosystems. ${ }^{13}$

Worldwide, water contaminated with crude oil is usually stored in evaporation pits before eventual discharge into the environment without any treatment. The remediation of such oilcontaminated water has become a crucial problem in oilproducing countries and requires immediate attention. ${ }^{4,14-16}$ Most drilling and extraction sites are in remote and hilly areas. Moreover, the majority of oil and/or gas wells are not highly productive at the time of their installation or lose their efficiency after some time. Conventional methods of oil-contaminated water treatment based on physical and chemical processes are not feasible to install in developing countries due to their high capital, operational, and maintenance costs. ${ }^{16,17}$ Therefore, it is difficultboth practically and economically-to develop oil-contaminated water treatment plants for oil and gas companies in these countries.

Using floating treatment wetlands (FTWs) is an innovative approach for the remediation of polluted water, which requires only vegetation attached to buoyant mats. ${ }^{18-21}$ They can be applied to any oil-contaminated water stabilization pit with minimal financial capital. Recent studies have revealed that the combined use of plants and bacteria in FTWs can enhance plant growth and pollutant degradation. ${ }^{18,22,23}$ Plants provide nutrients to rhizospheric microbes through their root exudates. These microorganisms have major roles in the degradation of organic compounds, and their efficiency in degrading hydrocarbons increases in the presence of plants. ${ }^{24-28}$ Once the pollutant is taken up by the plant, endophytes are actively involved in the in planta degradation. ${ }^{26,27}$ However, this combination of plants and associated microbes has not yet been evaluated at large scales for remediation of oil-contaminated water.

The aim of this study was to evaluate the remediation efficiency of oil-contaminated water generated as a waste product by an oil and gas company by applying FTWs to its oil-contaminated water $\left(22.326 \mathrm{~m}^{3}\right)$ stabilization pit. Four different plant species were used to develop FTWs, which were then inoculated with bacteria possessing capabilities of hydrocarbon degradation, rhamnolipid production, and plant growth promotion. Plant growth and

\footnotetext{
${ }^{1}$ Soil and Environmental Biotechnology Division, National Institute for Biotechnology and Genetic Engineering (NIBGE), Faisalabad, Pakistan; ${ }^{2}$ Pakistan Institute of Engineering and Applied Sciences (PIEAS), Islamabad, Pakistan; ${ }^{3}$ Environmental Biology Laboratory, Department of Biological Sciences, Michigan Technological University, Houghton, MI 49931, USA and ${ }^{4}$ Department of Bioscience, Aarhus University Centre for Water Technology (WATEC), Aarhus University, 8000 Århus C, Denmark Correspondence: Muhammad Afzal (manibge@yahoo.com)
}

Received: 6 July 2018 Accepted: 2 November 2018

Published online: 10 January 2019 
reduction in pollutant content were monitored for 18 months. In addition, bacterial colonization and metabolic activities were monitored in the rhizoplane and endosphere of the plants. To our knowledge, this is the first report on the large-scale treatment of oil-contaminated water in the stabilization pit of an oil and gas company.

Table 1. Characteristics of the crude oil-contaminated water collected from a pit resulting from oil and gas exploitation in Chakwal, Pakistan

\begin{tabular}{|c|c|c|}
\hline Parameter & Value & NEQS \\
\hline $\mathrm{pH}$ & $7.49(0.1)$ & $6-9$ \\
\hline Chemical oxygen demand (COD) $\left(\mathrm{mg} \mathrm{l}^{-1}\right)$ & $1316(73.5)$ & 150 \\
\hline Biochemical oxygen demand $\left(\mathrm{BOD}_{5}\right)\left(\mathrm{mgl}^{-1}\right)$ & $365(15.4)$ & 80 \\
\hline Hydrocarbons $\left(\mathrm{mgl}^{-1}\right)$ & 319 (9.7) & 10 \\
\hline Dissolved oxygen $\left(\mathrm{mg} \mathrm{l}^{-1}\right)$ & $0.57(0.03)$ & NG \\
\hline Total dissolved solids (TDS) $\left(\mathrm{mg} \mathrm{l}^{-1}\right)$ & $8050(113)$ & 3500 \\
\hline Chlorides $\left(\mathrm{Cl}^{-}\right)\left(\mathrm{mg} \mathrm{l}^{-1}\right)$ & $1330(73)$ & 1000 \\
\hline Sulfates $\left(\mathrm{SO}_{4}{ }^{2-}\right)\left(\mathrm{mg} \mathrm{I}^{-1}\right)$ & $432(9.3)$ & 600 \\
\hline Nitrogen $\left(\mathrm{mgl}^{-1}\right)$ & $0.8(0.04)$ & NG \\
\hline Phosphorous (P) ( $\left.\mathrm{mg} \mathrm{I}^{-1}\right)$ & $0.6(0.02)$ & NG \\
\hline Sodium $\left(\mathrm{Na}^{+}\right)\left(\mathrm{mg} \mathrm{I}^{-1}\right)$ & $2467(143)$ & NG \\
\hline Potassium $\left(\mathrm{K}^{+}\right)\left(\mathrm{mg} \mathrm{I}^{-1}\right)$ & $1378(64)$ & NG \\
\hline Cadmium (Cd) $\left(\mathrm{mg} \mathrm{l}^{-1}\right)$ & $0.98(0.06)$ & 0.1 \\
\hline Chromium (Cr) (mg I $\left.{ }^{-1}\right)$ & $0.86(0.03)$ & 1.0 \\
\hline Copper (Cu) $\left(\mathrm{mg} \mathrm{I}^{-1}\right)$ & $0.20(0.01)$ & 1.0 \\
\hline Iron $(\mathrm{Fe})\left(\mathrm{mg} \mathrm{I}^{-1}\right)$ & $1.52(0.08)$ & 8 \\
\hline Nickel (Ni) (mg I $\left.{ }^{-1}\right)$ & $0.53(0.03)$ & 1.0 \\
\hline Lead $(\mathrm{Pb})\left(\mathrm{mg} \mathrm{l}^{-1}\right)$ & $0.62(0.02)$ & 0.5 \\
\hline
\end{tabular}

Each value is a mean of three replicates; standard deviations are presented within parentheses

$N G$ not given in NEQS list, NEQS National environmental quality standards

\section{RESULTS AND DISCUSSION}

Characteristics of oil-contaminated water

The physicochemical characteristics of the pre-treatment water contaminated with oil revealed values of COD (1316 $\left.\mathrm{mg} \mathrm{I}^{-1}\right), \mathrm{BOD}_{5}$ $\left(365 \mathrm{mgl}^{-1}\right)$, hydrocarbon content $\left(319 \mathrm{mgl}^{-1}\right)$, total dissolved solids (TDS) $\left(8050 \mathrm{mg} \mathrm{I}^{-1}\right)$, chlorides $\left(1330 \mathrm{mg} \mathrm{I}^{-1}\right), \mathrm{Cd}(0.98 \mathrm{mg}$ $\left.\mathrm{I}^{-1}\right)$, and $\mathrm{Pb}\left(0.62 \mathrm{mgl}^{-1}\right)$ that were higher than the oilcontaminated water discharge standards of Pakistan. ${ }^{29}$ However, very low concentrations of total nitrogen $\left(0.8 \mathrm{mgl}^{-1}\right)$ and phosphorus $\left(0.6 \mathrm{mg} \mathrm{l}^{-1}\right)$ were observed (Table 1).

\section{Remediation of oil-contaminated water}

The analyses of organic and inorganic contaminants throughout the experimental period of 18 months provided deep insights into the application of FTWs vegetated with the four different plant species (Typha domingensis, Phragmites australis, Leptochloa fusca, and Brachiaria mutica) at the large scale (Table 2 and Fig. 1). There was a continual decrease in contamination level over time; however, a rapid decline in pollution load was observed within the first 6 months of treatment, suggesting quick adaptability of the plants to water contaminated by crude oil. Some plant species have a natural ability to use their metabolic processes for detoxifying toxic compounds. ${ }^{30-32}$

Among the different pollution parameters tested, hydrocarbons were reduced from 321 to $2.8 \mathrm{mg} \mathrm{I}^{-1}$ (99.13\%) within 18 months of applying the FTWs (Fig. 1a). In an earlier study, only $62 \%$ hydrocarbon removal was observed when applying FTWs vegetated with Vetiverria zizanioides. ${ }^{6}$ Our findings suggest that augmenting FTWs with a specific hydrocarbon-degrading bacterial consortium improves the traditional phytoremediation system by enhancing the capability of both plants and microbes to degrade recalcitrant compounds. This plant-bacterial synergism for hydrocarbon degradation in water has been reported in earlier studies. $^{6,26,27,33}$ In our findings, a major reduction in hydrocarbon content was already observed in the first 6 months of treatment with FTWs. This might have resulted from the presence at the start of treatment of easily degradable hydrocarbons in the oil-

\begin{tabular}{|c|c|c|c|c|c|c|c|c|c|c|}
\hline TDS & $8061^{a}(453)$ & $6252^{\mathrm{b}}(564)$ & $4117^{c}(734)$ & $3652^{d}(568)$ & $2987^{e}(342)$ & $2883^{\mathrm{e}}(367)$ & $2467^{f}(235)$ & $2193^{f}(238)$ & $1656^{\mathrm{g}}(198)$ & $1417^{\mathrm{h}}(203)$ \\
\hline DO & $0.58^{\mathrm{d}}(0.05)$ & $2.67^{\mathrm{c}}(0.06)$ & $4.88^{\mathrm{b}}(0.09)$ & $6.98^{\mathrm{a}}(0.08)$ & $6.25(0.15)$ & $6.81^{\mathrm{a}}(0.25)$ & $6.73^{\mathrm{a}}(0.134)$ & $6.80^{\mathrm{a}}(0.25)$ & $6.72^{\mathrm{a}}(0.35)$ & $6.75^{\mathrm{a}}(0.55)$ \\
\hline $\mathrm{Cl}$ & $1339^{\mathrm{a}}(106)$ & $1135^{\mathrm{a}, \mathrm{b}}(113)$ & $926^{\mathrm{b}}(39)$ & $793^{c}(19.8)$ & $638^{\mathrm{d}}(14.7)$ & $596^{\mathrm{e}}(14.3)$ & $348^{f}(9.55)$ & $212^{\mathrm{g}}(11.8)$ & $171^{\mathrm{h}}(8.4)$ & $108^{i}(7.5)$ \\
\hline $\mathrm{SO}_{4}$ & $434^{\mathrm{a}}(7.02)$ & $348^{\mathrm{b}}(8.9)$ & $298^{c}(5.94)$ & $189^{d}(4.98)$ & $138^{\mathrm{e}}(7.52)$ & $117^{f}(7.25)$ & $101^{9}(7.50)$ & $88^{\mathrm{h}}(7.15)$ & $78^{\mathrm{h}, \mathrm{i}}(3.86)$ & $64^{i}(1.2)$ \\
\hline $\mathrm{Cd}$ & $0.91^{\mathrm{a}}(0.07)$ & $0.83^{\mathrm{b}}(0.05)$ & $0.71^{\mathrm{b}, \mathrm{c}}(0.03)$ & $0.66^{\mathrm{c}}(0.09)$ & $0.58^{c, d}(0.02)$ & $0.49^{d}(0.04)$ & $0.37^{\mathrm{e}}(0.07)$ & $0.21^{f}(0.05)$ & $0.16^{f}(0.02)$ & $0.11^{\mathrm{g}}(0.04)$ \\
\hline $\mathrm{Cr}$ & $0.83^{\mathrm{a}}(0.03)$ & $0.61^{b}(0.05)$ & $0.57^{\mathrm{b}}(0.02)$ & $0.42^{\mathrm{c}}(0.01)$ & $0.35^{d}(0.02)$ & $0.27^{\mathrm{e}}(0.05)$ & $0.18^{f}(0.02)$ & $0.12^{\mathrm{g}}(0.01)$ & $0.09^{\mathrm{h}}(0.004)$ & $0.04^{i}(0.002)$ \\
\hline $\mathrm{Cu}$ & $0.21^{\mathrm{a}}(0.04)$ & $0.14^{\mathrm{b}}(0.02)$ & $0.09^{\mathrm{c}}(0.01)$ & $0.07^{c . d}(0.01)$ & $0.06^{d}(0.001)$ & $\begin{array}{l}0.05^{\text {d.e }} \\
(0.001)\end{array}$ & $0.04^{e}(0.001)$ & $0.02^{f}(0.003)$ & $0.01^{\mathrm{g}}(0.003)$ & $0.01^{\mathrm{g}}(0.003)$ \\
\hline \multicolumn{11}{|c|}{$\begin{array}{l}\text { All values are in } \mathrm{mg} \mathrm{I}^{-1} \text { except the } \mathrm{pH} \text {. Values are means of three samples collected from the pit every } 2 \mathrm{~h} \text { on the day of visit to the pit. Each value is a mean of } \\
\text { three replicates, values within parentheses indicate the standard deviation and labels (a)-(I) indicate statistically significant differences between values in the } \\
\text { row at a } 5 \% \text { level of significance } \\
\mathrm{TDS} \text { total dissolved solids, } \mathrm{DO} \text { dissolved oxygen, } \mathrm{Na}^{+} \text {sodium, } \mathrm{K}^{+} \text {potassium, } \mathrm{Cl}^{-} \text {chloride, } \mathrm{SO}_{4}^{2-} \text { sulfate, } \mathrm{N} \text { nitrogen, } \mathrm{P} \text { phosphorus, } \mathrm{Cd} \text { cadmium, } \mathrm{Cr} \text { chromium, } \\
\mathrm{Cu} \text { copper, } \mathrm{Fe} \text { iron, } \mathrm{Ni} \text { nickel, } \mathrm{Pb} \text { lead }\end{array}$} \\
\hline
\end{tabular}



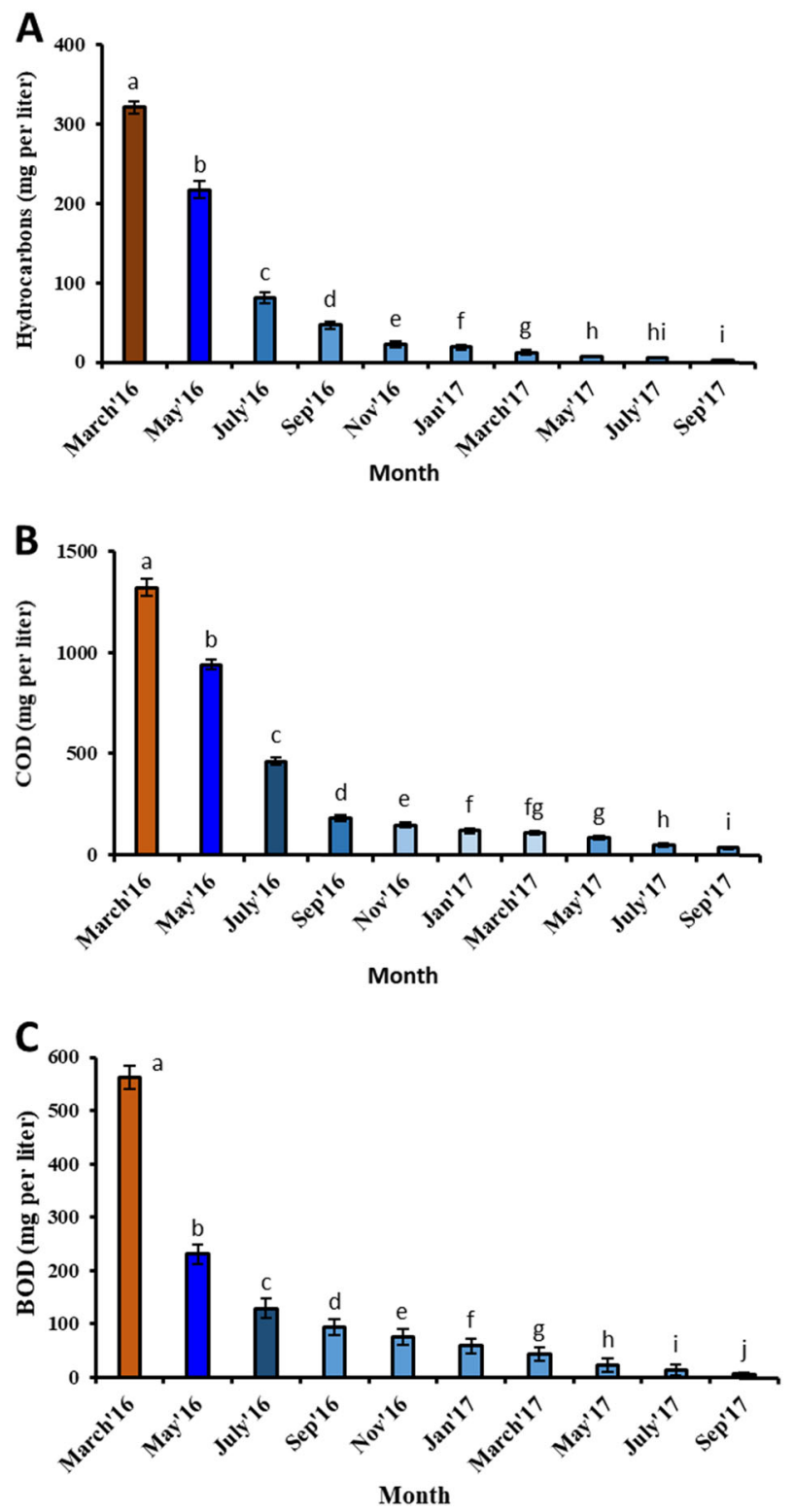

Fig. 1 Reduction in hydrocarbons a, COD (chemical oxygen demand) b, and BOD (biochemical oxygen demand) $\mathbf{c}$ in the oilcontaminated water in 18 months by the application of floating treatment wetlands. Each value is mean of three replicates and labels a-f indicate statistically significant differences between values at a $5 \%$ level of significance

contaminated water, which decreased in concentration over time. ${ }^{33}$

Other major parameters defining the health of aquatic ecosystems are $C O D$ and $\mathrm{BOD}_{5}$, for which low values of $\mathrm{COD}$ and $\mathrm{BOD}_{5}$ indicate cleaner water. In this study, $\mathrm{COD}$ and $\mathrm{BOD}_{5}$ were reduced by $97.43 \%$ and $98.93 \%$, respectively, after 18 months of applying FTWs in the pit (Figs $1 \mathrm{~b}, \mathrm{c}$ ). This decomposition of organic matter can be attributed to the synergism established between microbial biofilms in the rhizoplane and the plant roots that help diffuse oxygen into the plant rhizoplane. ${ }^{31,34}$ With respect to other physiochemical parameters, the $\mathrm{pH}$ of the water decreased (7.55 to 6.99) over the whole study period (Table 2). Reduction in $\mathrm{pH}$ can be attributed to the microbial degradation of organic matter and production of acids; plants also produce acidic root exudates, which can shift the $\mathrm{pH}$ of water towards acidity. ${ }^{35-37}$
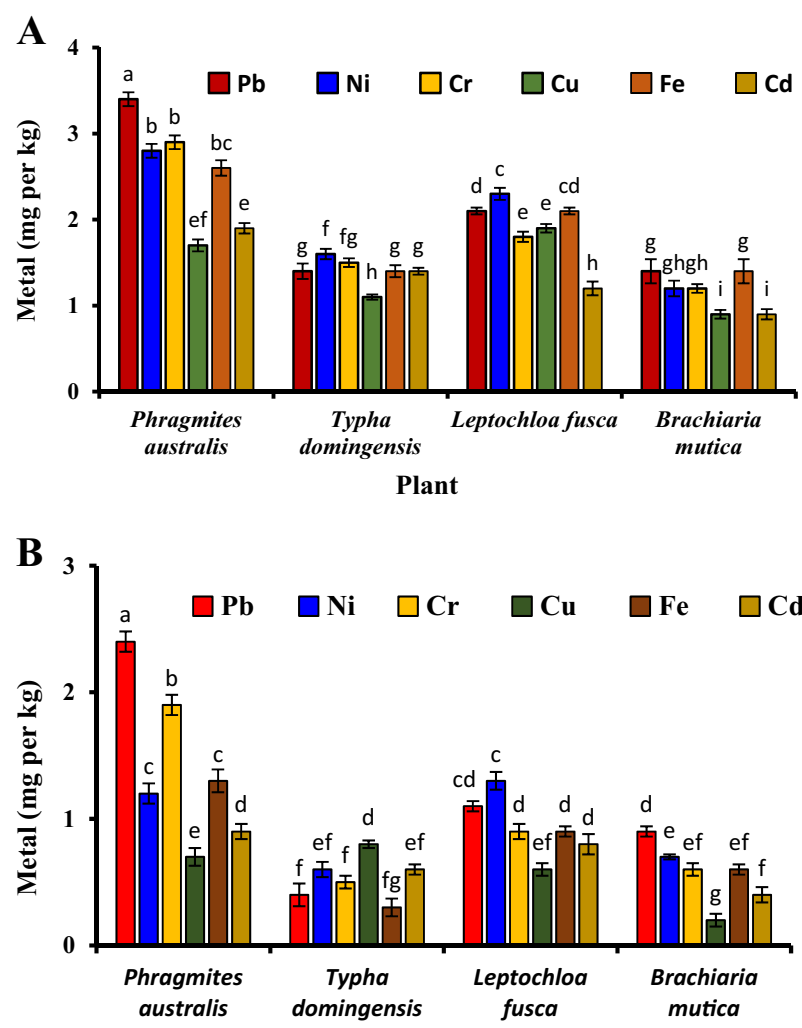

Plant

Fig. 2 Metal accumulation in the roots $\mathbf{a}$ and shoots $\mathbf{b}$ of different plans vegetated in floating mats for the development of floating treatment wetlands. Each value is mean of three replicates and labels a-f indicate statistically significant differences between values at a $5 \%$ level of significance

TDS decreased (82.42\%) steadily with time following treatment by FTWs in the pit (Table 2). The concentrations of $\mathrm{Na}^{+}, \mathrm{K}^{+}, \mathrm{SO}_{4}{ }^{2-}$, and $\mathrm{Cl}^{-}$were also reduced in the same proportion as the TDS. This might be due to the uptake of these elements by the plants and microbes and/or their adsorption onto the roots of the plants. Plants absorb inorganic elements from the wastewater, transport them to the aerial parts through the xylem, and finally sequester them in their roots and shoots. ${ }^{38-40}$ The process of bacterialassisted phytoremediation in FTWs is analogous to rhizo/phyto degradation in the soil, where the bacterial consortia in the rhizospheres of plants work synergistically with their host to efficiently reduce the concentration of contaminants.

\section{Heavy metal removal}

In this study, the removal efficiencies of the tested heavy metals from the oil-contaminated water were in the following order: Fe $(99.9 \%)>\mathrm{Cu}(95.2 \%)>\mathrm{Cr}(95 \%)>\mathrm{Pb}(93.54 \%)>\mathrm{Cd}(88.8 \%)$ and $\mathrm{Ni}$ (84.9\%) (Table 2). A higher abundance of microbes in the environment has been proposed to reduce the toxicity of metals. ${ }^{41,42}$ Consistent with the decrease in metal concentrations found in oil-contaminated water over time, plant roots and shoots were observed to accumulate more metals at each harvest (Fig. 2). This can be attributed to the enhancement in translocation of metals from the roots to the leaves by bacteria in the rhizoplane. Bacteria do this by enhancing the bioavailability of metals in the rhizosphere or by promoting an increase in root length, total root surface area, or number of root hairs for entrapping these pollutants. ${ }^{39,43}$ Previous studies have also revealed that the bioavailability of trace elements increases with higher microbial population and activity. ${ }^{44,45}$ Hence, microbes and plants work best 
in combination to reduce heavy metals in wastewater by improving their bioavailability and uptake by plants. ${ }^{46}$

All the plants used in this study have previously been reported to remove trace elements from oil-contaminated water through a mechanism known as phytoextraction. ${ }^{18,22,47,48}$ In this study, metal accumulation in the four species used to vegetate the FTWs was in the order of $P$. australis $>T$. domingensis $>L$. fusca $>$ and $B$. mutica. Phragmites australis has been previously reported as an ideal plant to accumulate moderate amounts of metal contaminants while retaining high biomass production. ${ }^{33,49,50}$

\section{Persistence of inoculation bacteria}

In phytoremediation, hydrocarbons are mineralized by plantassociated microbial populations. ${ }^{27,36,51}$ In the present study, all of the inoculation bacteria showed a high level of persistence (colony-forming unit (CFU) and alkB gene abundance) and activity (alkB gene expression) in the oil-contaminated water, rhizoplane, as well as in the root and shoot interiors (Table 3 ). This might be due to the fact that the bacteria used for inoculation originated from crude oil-contaminated soil and/or plants growing in such soil; being from such sources means that they already have mechanisms/catabolic genes for growth and proliferation in the presence of hydrocarbons.

Although bacterial augmentation was applied to both the roots of the plants and the oil-contaminated water, the highest numbers of inoculate bacteria were found in the rhizoplane, followed by the root and shoot interiors and then oilcontaminated water. This may have resulted from the larger surface area provided by the roots of the plants that extend below the water surface and are thus able to support microbial proliferation by ensuring the availability of nutrients and habitat for microbes. ${ }^{52-54}$ Among the inoculation strains, the endophytic bacteria Klebsiella sp. strain LCRI-87, Bacillus subtilus LORI66, and Acinetobacter sp. BRSI56 showed higher colonization and activity inside the plant roots and shoots compared with the other inoculation strains. On the other hand, two strains, Microbacterium oryzae R4 and Pseudomonas aeruginosa R25, showed minimum persistence and activity in different tissues of the plants. Although all these strains were used to inoculate both the roots and the oilcontaminated water, these results support previous findings that, as expected, endophytes have more potential to colonize plant interiors while rhizospheric bacteria preferably reside outside the plant. $^{36,55}$

The bacterial population and activity decreased in the oilcontaminated water over time. However, in the rhizoplane, roots, and shoots, both abundance and expression were enhanced during the first 6 months of inoculation followed by a decrease. This may be due to the reduction in the content of bioavailable hydrocarbons over time; also, it is possible that the remaining hydrocarbons were not readily biodegradable. ${ }^{36}$ Among the four plant species used to vegetate the FTWs, $P$. australis hosted the highest number of bacteria with higher abundance and expression of the hydrocarbon-degrading gene $(a / k B)$ as compared with the other plant species. This can be explained by the release of different nutrients from each species, which stimulates only specific microorganisms to form a synergistic relationship with the plant. Thus, colonization of inoculate bacteria in the rhizoplane and endosphere depends not only on the type and amount of contaminants but also on the plant species. ${ }^{36,51,56}$ Another possible reason may be that $P$. australis exhibited better growth and development than other plants, which means that it was also able to provide more nutrients and space for microbial colonization and activity.

\section{Plant growth}

The plants were harvested every 3 months; root and shoot lengths and dry biomass were determined as described earlier. ${ }^{22}$ All the plants, P. australis, T. domingensis, L. fusca, and B. mutica, exhibited growth above the mat with the development of roots beneath the water, which provided evidence that these grasses acclimatize well to the hydrocarbon-polluted environment. This may be due to the partnership developed between the inoculate microbes and plants. These microbes have several plant growth-promoting traits that help ameliorate hydrocarbon-induced stress and thus increase plant growth and development. ${ }^{27,51,57}$

Average plant dry biomass above the mat was $1.27,0.71,0.67$, and $0.56 \mathrm{~kg} \mathrm{~m}^{-2}$ for $P$. australis, $T$. domingensis, B. mutica, and $L$. fusca, respectively (Fig. 3a). The average root biomass below the mat was $0.38,0.35,0.24$, and $0.20 \mathrm{~kg} \mathrm{~m}^{-2}$ for $P$. australis, $T$. domingensis, B. mutica, and $L$. fusca, respectively (Fig. $3 \mathrm{~b}$ ). The average lengths of roots and shoots in the four tested species were 76.22 and 252.94, 64.21 and 228.62, 39.62 and 106.68, and 27.43 and $207.26 \mathrm{~cm}$ for $P$. australis, T. domingensis, L. fusca, and $B$. mutica, respectively (Fig. $3 \mathrm{~b}$ ). These results suggest that all four plant species had different rates of growth and biomass production, among which $P$. australis exhibited significantly higher biomass and overall development. As mentioned before, this can be due to their varying abilities to host microbes, which may ultimately enhance the development of different plant tissues (root and shoot). ${ }^{58-60}$

\section{Detoxification of oil-contaminated water}

Fish survival analysis showed that after 6 and 12 months of applying FTWs in the pit, treated oil-contaminated water was only partially detoxified as indicated by the death of three and two fish, respectively, at those times. However, after 18 months, no fish expired, which indicates the complete detoxification of the oilcontaminated water from the stabilization pit (Table 4). This can be attributed to the removal of salts and hydrocarbons from the oil-contaminated water by the combined action of plants and bacteria. ${ }^{18,47}$ In view of these findings, FTWs are proposed as favorable and advantageous ecotechnology to restore the quality of water reservoirs.

The results obtained from using FTWs used to treat an oilcontaminated water stabilization pit generated by oil and gas exploitation provide evidence that it is a promising approach for the remediation of oil-contaminated water in this industry. Phragmites australis showed significantly better growth and development than the other three plant species used in this study. Inoculation bacteria showed not only persistence in the rhizosphere and endosphere but also remained metabolically active in the degradation of hydrocarbons. The successful removal of organic and inorganic pollutants from the oil-contaminated water stabilization pit gives clear evidence of the potential of FTWs to improve the quality of water.

\section{METHODS}

\section{Site description}

The FTWs were used to treat oil contamination in the water stabilization pit of an oil and gas exploration company located in the district of Chakwal in Pakistan $\left(33^{\circ} 01^{\prime} 30.4^{\prime \prime} \mathrm{N} 73^{\circ} 09^{\prime} 18.3^{\prime \prime} \mathrm{E}\right)$. This closed pit $(122 \mathrm{~m} \times 61 \mathrm{~m})$ with no inlet or outlet was built in 2014 and has been filled with crude oilcontaminated water since. Depth in the center of the pit is about $3 \mathrm{~m}$ from the surface of the oil-contaminated water. Chakwal is located in a semi-arid steppe climate with $519 \mathrm{~mm}$ of annual precipitation. The range of average temperature in summer lies between $15^{\circ} \mathrm{C}$ and $40^{\circ} \mathrm{C}$, and the winter temperatures are between $-4{ }^{\circ} \mathrm{C}$ and $25^{\circ} \mathrm{C}$.

\section{Floating mat}

The floating mat was made out of a Jumbolon role (cells of polyethylene resins) (http://jumbolon.com/jumbolon-rolls/). This material was selected to develop the floating mat due to its durability, flexibility, and high buoyancy. The mat was designed and constructed at NIBGE. Each mat (area of $7.32 \mathrm{~m}^{2}$ ) had dimensions of $1.83 \mathrm{~m} \times 1.22 \mathrm{~m} \times 0.10 \mathrm{~m}$ (length $\times$ 


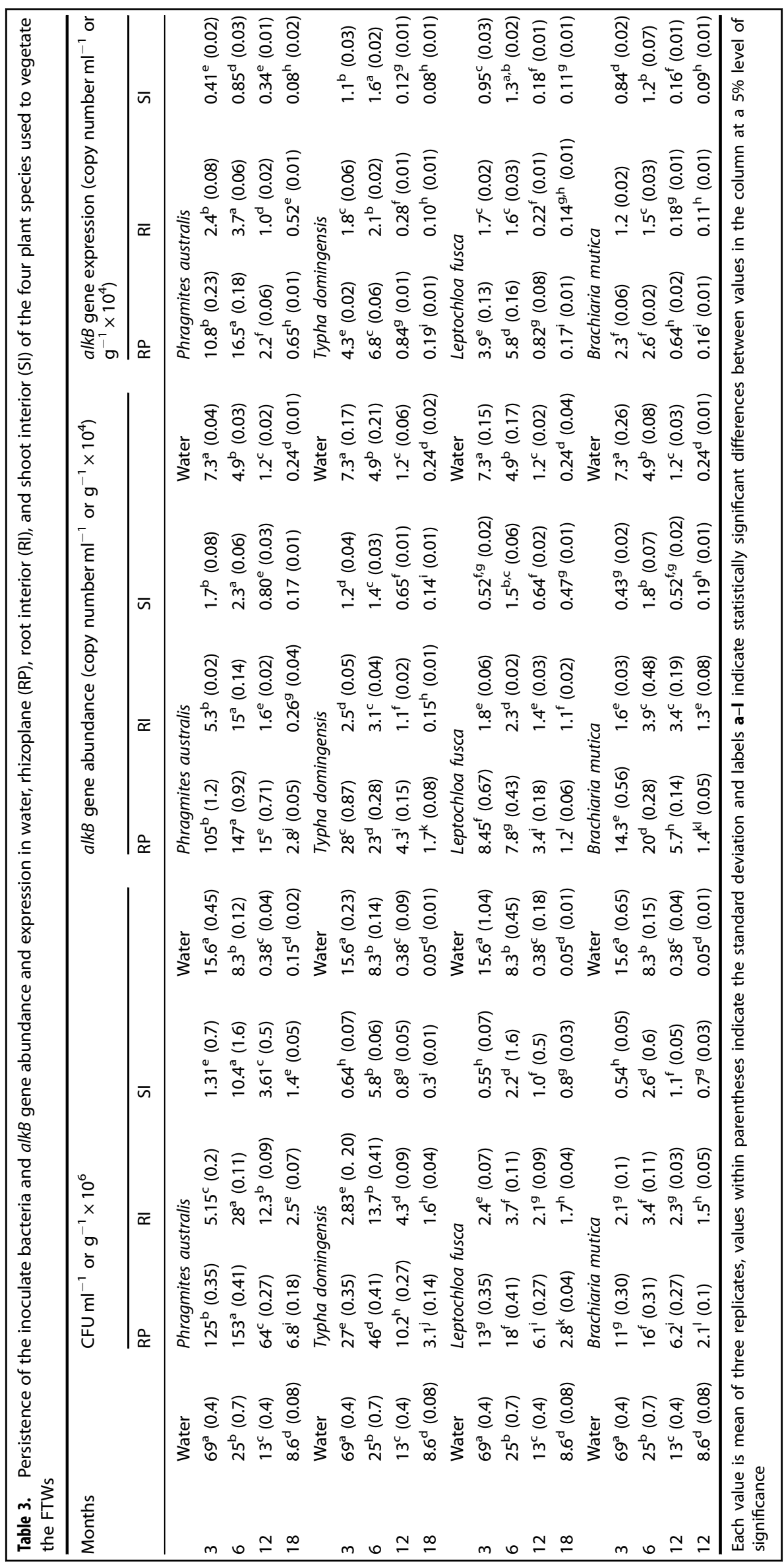


6

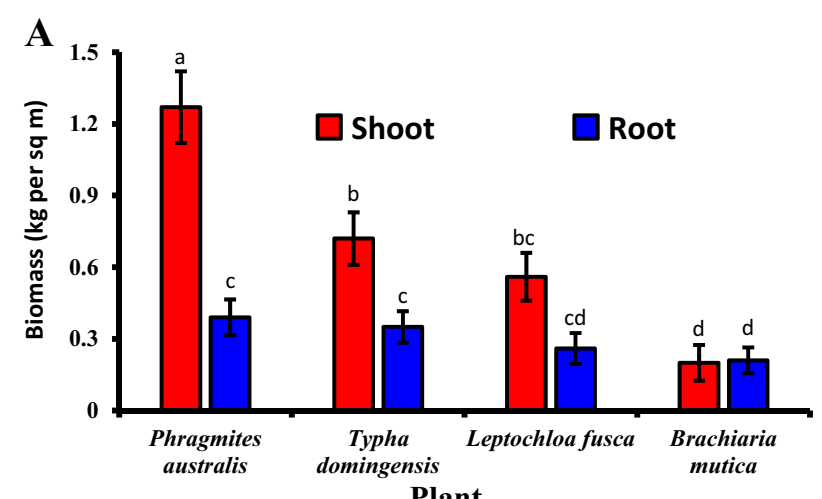

Plant

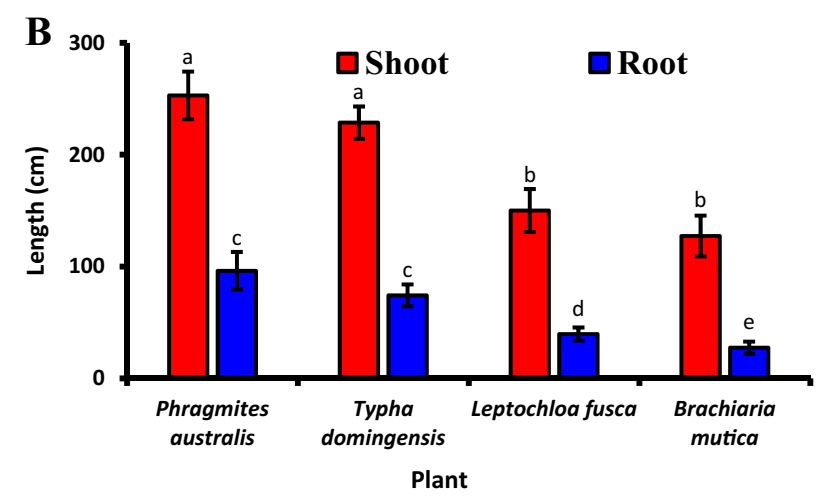

Fig. 3 Dry biomass $\mathbf{a}$ and length $\mathbf{b}$ of root and shoot of different plans vegetated in floating mats for the development of floating treatment wetlands. Each value is mean of three replicates and labels a-f indicate statistically significant differences between values at a $5 \%$ level of significance width $\times$ height) with a $2.54 \mathrm{~cm}$ border on all sides (Fig. 4). The borders were covered with aluminum foil to protect the mat from sunlight. Fourteen holes $(12.7 \mathrm{~cm}$ diameter on the upper side and $10.16 \mathrm{~cm}$ diameter on the lower side) were drilled into each mat in a manner so that there were five holes along both sides of the mat lengthwise and four holes along the midline. Small holes ( $2.54 \mathrm{~cm}$ diameter) were also drilled at each of the four corners and polypropylene random copolymer (PPRC) pipes (length $15.24 \mathrm{~cm}$ and diameter 2.54) were inserted into these holes (Fig. 4). These pipes were used to connect the mats with each other with the help of plastic-coated wires. A total of 218 mats were connected together to construct a floating island with a total area of $3058 \mathrm{~m}^{2}$ (Figs. 5, 6).

\section{Plants}

A nursery containing four plant species, two aquatic ( $P$. australis and $T$. domingensis) and two terrestrial (L. fusca and B. mutica), was grown using plastic pots (length $10.16 \mathrm{~cm}$, diameter $12.7 \mathrm{~cm}$, and a hole of diameter $7.62 \mathrm{~cm}$ at the bottom) in the botanical garden at National Institute for Biotechnology and Genetic Engineering (NIBGE), Faisalabad, Pakistan. The seedlings of $P$. australis and $T$. domingensis had been obtained from wastewater drains and pits in the surroundings of Faisalabad. The cuttings of $L$. fusca and B. mutica had been obtained from the Nuclear Institute for Agriculture and Biology, Faisalabad.

Table 4. Detoxification of oil-contaminated water by bacterialassisted floating treatment wetlands

\begin{tabular}{lllllll}
\hline $\begin{array}{l}\text { Time } \\
\text { (months) }\end{array}$ & $\begin{array}{l}\text { Fish deaths over } \\
\text { time }\end{array}$ & Total deaths & Detoxification status \\
\hline & $24 \mathrm{~h}$ & $48 \mathrm{~h}$ & $72 \mathrm{~h}$ & $96 \mathrm{~h}$ & & \\
0 & 10 & 0 & 0 & 0 & 10 & No \\
6 & 0 & 0 & 2 & 1 & 3 & Partially \\
12 & 0 & 0 & 1 & 1 & 2 & Partially \\
18 & 0 & 0 & 0 & 0 & 0 & Yes \\
\hline
\end{tabular}

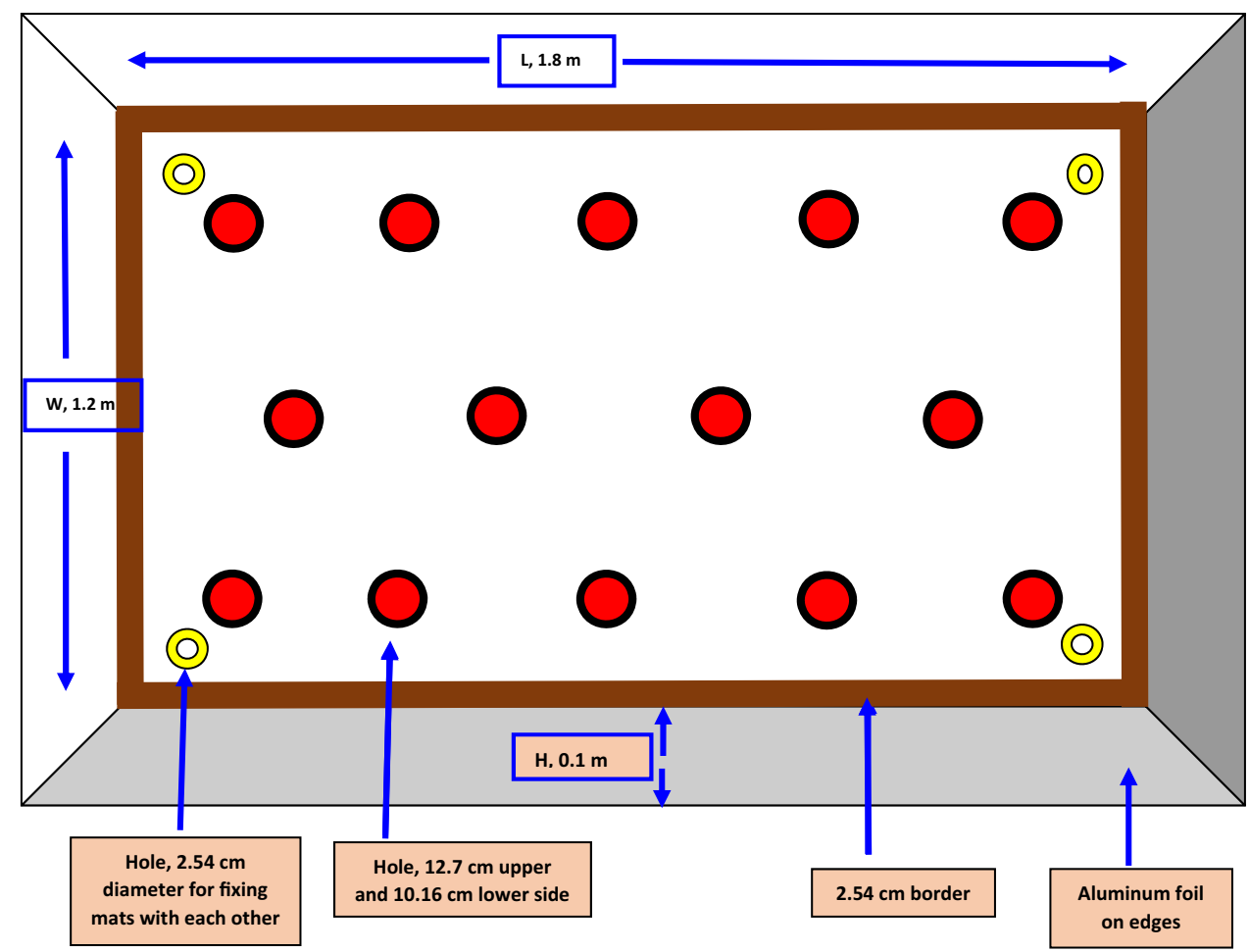

Fig. 4 Design of a floating mat for constructing a floating treatment wetland (FTW) for application in an oil-contaminated water pit generated by oil and gas exploitation 

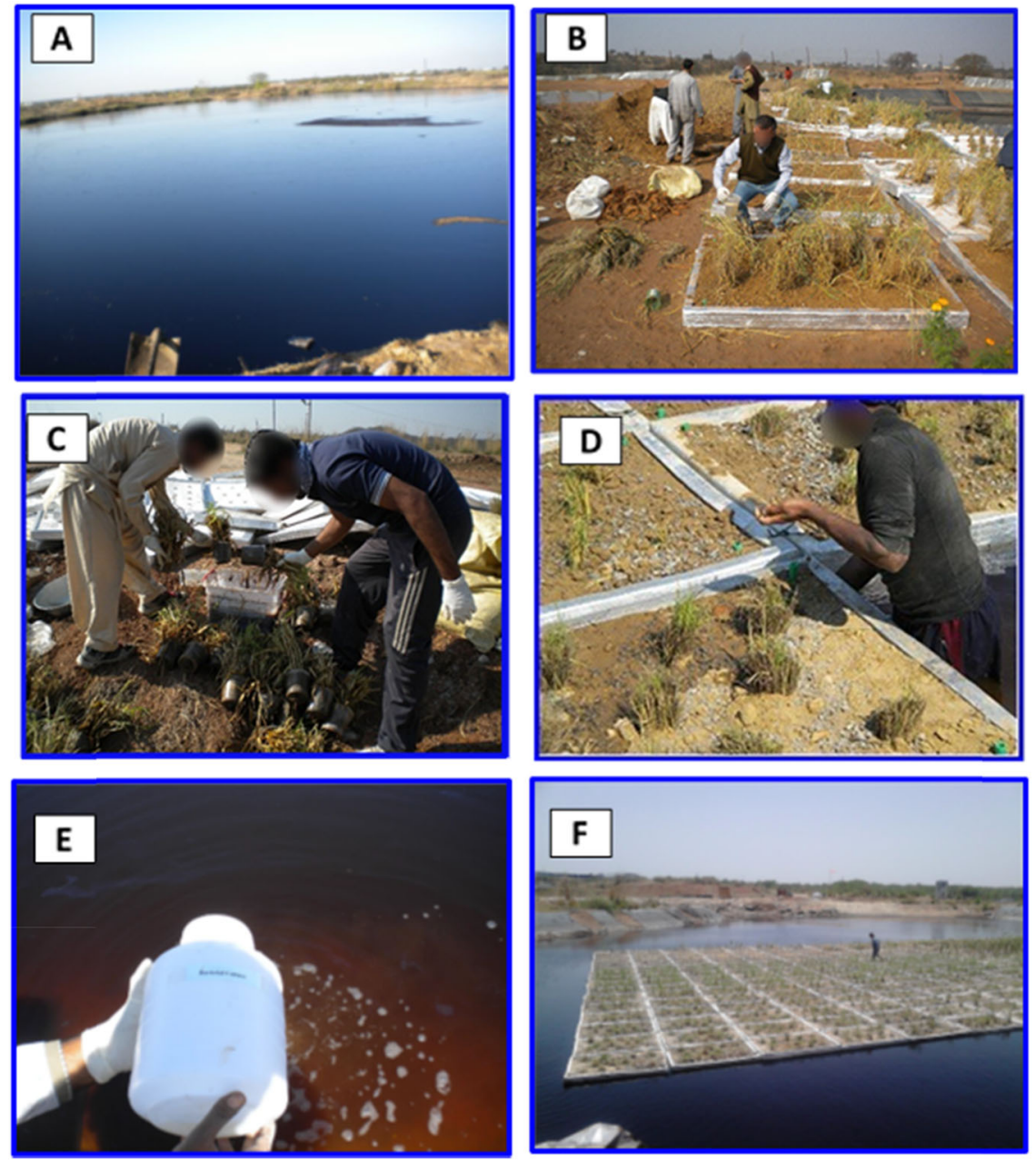

Fig. 5 a-f Application of floating treatment wetlands in the oil-contaminated water stabilization pit of an oil and gas company. Oilcontaminated water stabilization pit $\mathbf{a}$, vegetation of mats with plants and their inoculation with bacteria $\mathbf{b}$, $\mathbf{c}$, fixing of mats to each other $\mathbf{d}$, adding the bacteria to the pit $\mathbf{e}$, and the growth of the plants at the initial stage $\mathbf{f}$

\section{Bacterial strains}

Ten bacterial strains that had previously been isolated and characterized by Fatima et al. ${ }^{61}$ and Tahseen et al. ${ }^{62}$ were used in this study. These strains were Ochrobactrum intermedium R2, Microbacterium oryzae R4, Pseudomonas aeruginosa R25, P. aeruginosa R21 (isolated from crude oilcontaminated soil), Acinetobacter sp. LCRH81, Klebsiella sp. LCRI-87 (isolated from the rhizosphere and root interior of Lecucaena leucocephala, respectively), Acinetobacter sp. BRSI56, P. aeruginosa BRRI54 (isolated from the shoot and root interior of Brachiaria mutica, respectively), Bacillus subtilus LORI66 (isolated from the root interior of Lolium perenne), and Acinetobacter junii TYRH47 (isolated from the rhizosphere of $T$. domingensis). These strains are able to degrade hydrocarbons, produce biosurfactants, and promote plant growth (Table 5). Each strain was grown separately in LB broth (containing $1 \%\left(w^{-1}\right)$ diesel) overnight. Cells were recovered by centrifugation and suspended in normal saline solution $(0.9 \%$ $\mathrm{NaCl}$. An inoculum of each strain was prepared containing an equal number of cells by a turbidimetric method. ${ }^{62,63}$

\section{Application of FTWs in the pit}

A single pot with seedlings was put in each of the 14 holes for each mat. The mats were then covered with a $2.54 \mathrm{~cm}$ layer of soil $(70 \%)$, sand $(20 \%)$, and medium-sized gravel (10\%) to protect them from sunlight. A total of 418 mats were prepared: 200 mats were vegetated with P. australis, 118 with $T$. domingensis, and 50 each with $L$. fusca and B. mutica. As noted earlier, these mats were connected to one another using wires to make a single island. The total area thus covered by the floating island was $3058 \mathrm{~m}^{2}$, which was equivalent to $25 \%$ of the surface area of the pit (Figs. 5, 6).
Fifty kilograms of diammonium phosphate and urea fertilizer were added to the oil-contaminated water in the pit every 3 months for 18 months. Moreover, $10 \mathrm{~L}$ of the inoculum for each bacterial strain $\left(10^{9}\right.$ CFU $\mathrm{m}^{1-1}$ ) was added to the oil-contaminated water and the roots of the plants during this period.

\section{Sampling and analysis of oil-contaminated water}

Samples of oil-contaminated water were collected from the pit every 2 months from March 2016 to September 2017. These samples were preserved in glass bottles at $4{ }^{\circ} \mathrm{C}$ in an ice box, transported to the laboratory, and analyzed for various physicochemical parameters. The $\mathrm{pH}$ and electrical conductivity (EC) were measured using bench top equipment (XL 30, Fisher Scientific Pte Ltd. UE TechPark, Singapore). Chemical oxygen demand $(\mathrm{COD})$, biochemical oxygen demand $\left(\mathrm{BOD}_{5}\right)$, TDS, sulfates $\left(\mathrm{SO}_{4}{ }^{2-}\right)$, and chlorides $\left(\mathrm{Cl}^{-}\right)$were measured as described in an earlier study. ${ }^{64}$ Hydrocarbon content was measured using the Spectrum Two Environmental Hydrocarbons Analysis System (Perkin Elmer, USA), following extraction with hexane as the solvent. ${ }^{65}$ Total nitrogen $(\mathrm{N})$ and phosphorus (P) were estimated using a Millipore Cell Test Kit (Merck \& Co). Sodium $(\mathrm{Na})$ and potassium $(\mathrm{K})$ were measured using a flame photometer (FP 20, SEAC, Italy). Heavy metals, including $\mathrm{Cd}, \mathrm{Cr}, \mathrm{Cu}, \mathrm{Fe}, \mathrm{Ni}$, and $\mathrm{Pb}$, were determined quantitatively using atomic absorption spectroscopy (Varian SpectrAA.200, Varian Australia).

\section{Enumeration of inoculate bacteria}

The persistence and survival of the bacterial strains used to inoculate the FTWs were assessed for the rhizoplane, the root and shoot interiors, and 

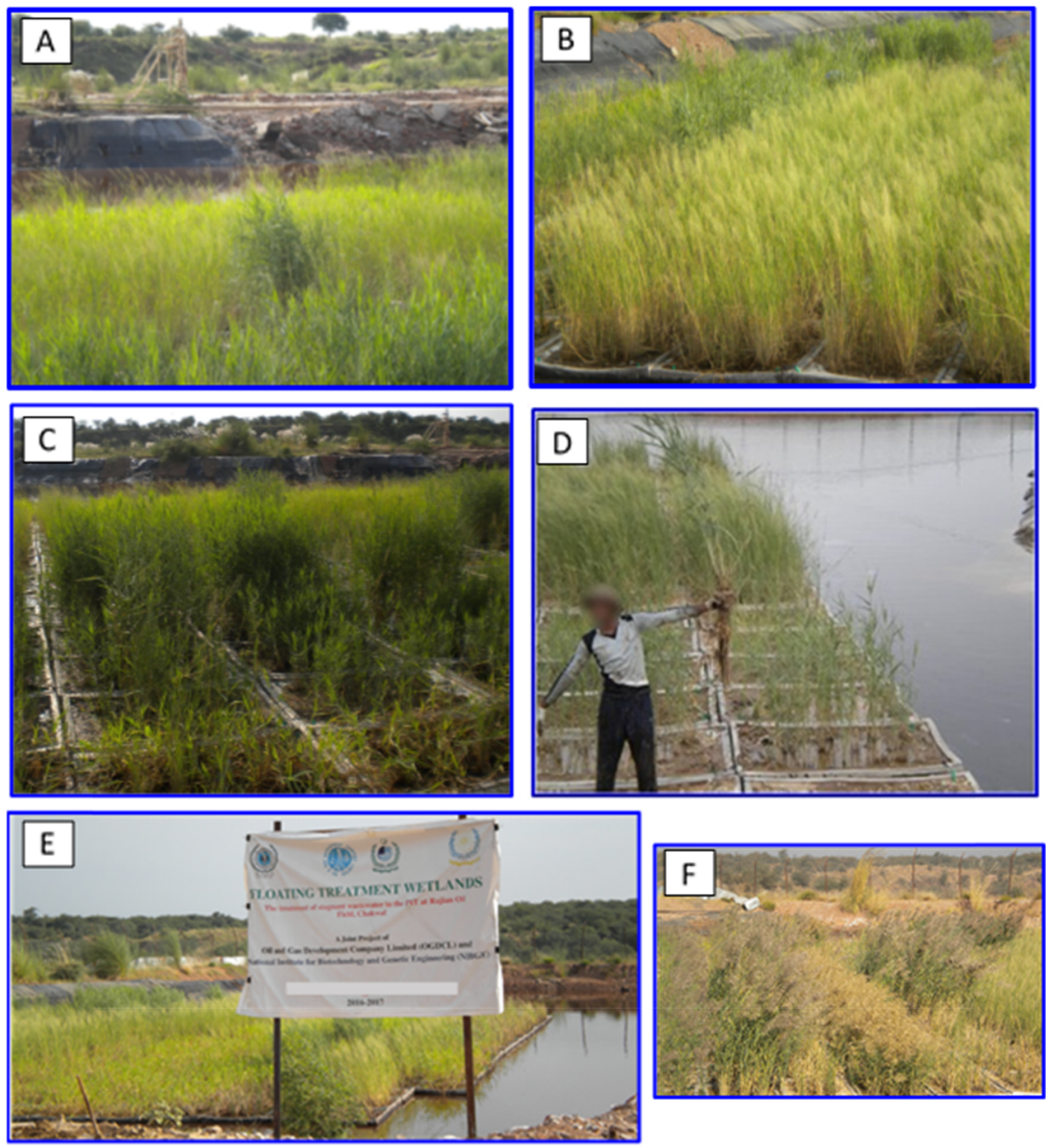

Fig. 6 a-f Growth of different plants used to vegetate the floating mats for remediating the oil-contaminated water stabilization pit. Growth of different plants a, shoot growth of $L$. fusca $\mathbf{b}$, shoot growth of $P$. australis $\mathbf{c}$, roots of $P$. australis $\mathbf{d}$, floating treatment wetlands (3058 $\left.\mathrm{m}^{2}\right) \mathbf{e}$, and fully grown $P$. australis $\mathbf{f}$

Table 5. Bacterial strains used to inoculate vegetation in the floating treatment wetlands

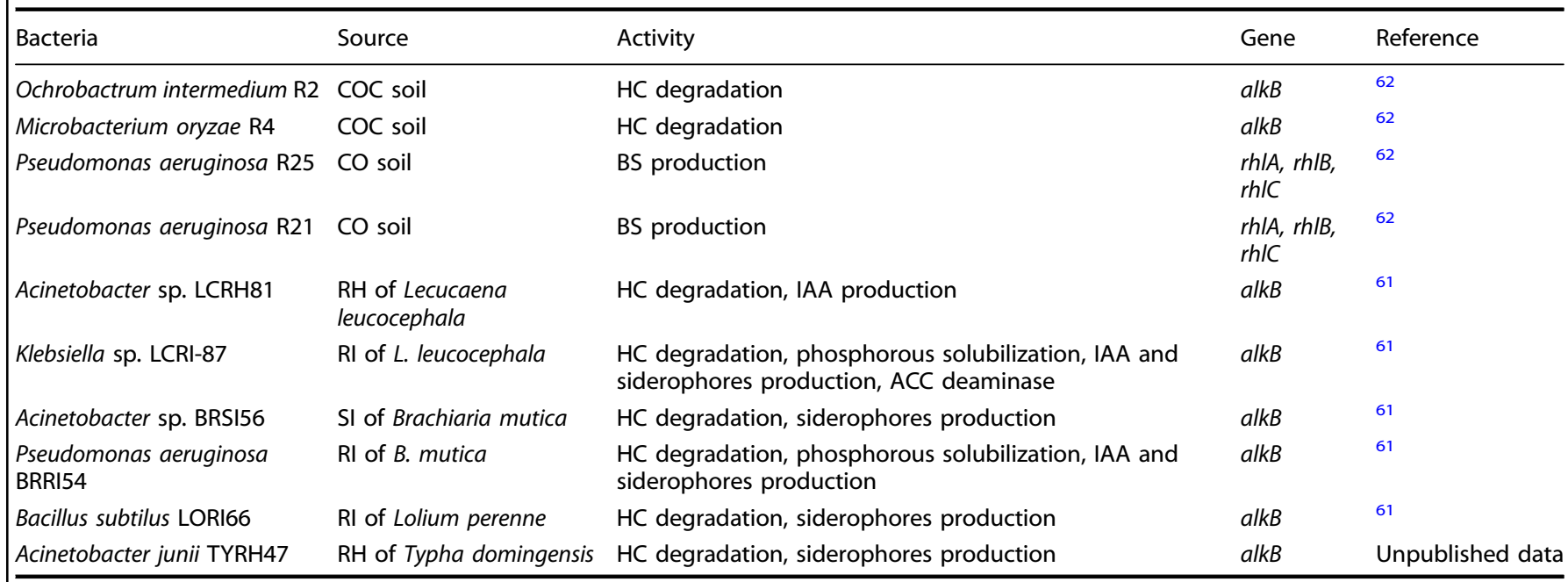

$C O C$ soil crude oil-contaminated soil, $R I$ root interior, $S I=$ shoot interior, $R H$ rhizosphere, $H C$ hydrocarbons, $B S$ biosurfactants, IAA indole acetic acid, $A C C$ 1amino-cyclopropane-1-carboxylic acid 
the oil-contaminated water of the pit by the plate count method as described in an earlier study. ${ }^{18,66}$ Bacteria from the rhizoplane were isolated by agitating roots in a normal saline solution containing $0.1-\mathrm{cm}$ (diameter) glass beads. The surfaces of roots and shoots were sterilized and homogenized in normal saline solution to isolate endophytes. Appropriate dilutions of the bacterial suspensions were plated on minimal media plates amended with $1 \%$ diesel. Similarly, different dilutions of oilcontaminated water samples were also plated on minimal medium containing $1 \%$ diesel. These plates were incubated at $37^{\circ} \mathrm{C}$. The inoculate strains were identified among the isolates by subjecting randomly selected colonies to restriction fragment length polymorphism analysis. ${ }^{67}$

Determination of alkB gene abundance and expression

The abundance and expression of the alkB gene were estimated in the rhizoplane, root and shoot interiors, and oil-contaminated water using realtime PCR as described in previously published studies. ${ }^{27,68}$ Briefly, DNA and RNA were isolated from roots, shoots, and oil-contaminated water using commercially available kits. RNA was then converted to complementary DNA (cDNA) with the help of reverse transcriptase. Following their synthesis, DNA and CDNA were used as templates for the estimation of alkB gene abundance and expression, respectively.

\section{Plant growth analysis}

Plants were harvested every 3 months. Roots were washed carefully with tap water to remove attached sludge. Plant tissue was then separated into shoots and roots, and their lengths were determined. The shoot and root samples were oven-dried at $70^{\circ} \mathrm{C}$ for $72 \mathrm{~h}$, and dry biomass was determined. ${ }^{69,70}$

\section{Evaluation of toxicity of treated water}

A sample of the treated oil-contaminated water was collected from the pit every 6 months for 18 months following the installation of the FTWs. All the collected samples were subject to toxicity analysis as described earlier. ${ }^{18,71}$ Briefly, ten healthy fish, Labeo rohita, of uniform weight and size were exposed to each treated sample in triplicate, and their survival rates were observed by counting the number of fish that expired every $24 \mathrm{~h}$ over 4 consecutive days.

\section{Statistical analysis}

Data (pollutants removal, plant biomass, and bacterial persistence) were analyzed with the software package SPSS (SPSS Inc., Chicago, IL, USA), and the standard deviation from mean values was calculated using Duncan's multiple range test.

\section{DATA AVAILABILITY}

All data reported in this study is available in this paper.

\section{ACKNOWLEDGEMENTS}

We thank the Higher Education Commission (HEC) of Pakistan for financial grant number 20-3854.

\section{AUTHOR CONTRIBUTIONS}

M.A., K.R., and G.S. designed and conducted the experiments. K.R., G.S., R.T., and A.J.H. contributed in wastewater analysis for different physicochemical parameters and also in determination of bacterial population, gene abundance and gene expression in water, and in rhizosphere and endosphere of the plants. A.I. and H.B. were involved in data analysis and manuscript preparation.

\section{ADDITIONAL INFORMATION}

Competing interests: The authors declare no competing interests.

Publisher's note: Springer Nature remains neutral with regard to jurisdictional claims in published maps and institutional affiliations.

\section{REFERENCES}

1. Coelho, A., Castro, A. V., Dezotti, M. \& Sant'Anna, G. L. Treatment of petroleum refinery sourwater by advanced oxidation processes. J. Hazard. Mater. 137, 178-184 (2006)

2. Strubinger, A., Ehrmann, U., León, V., DeSisto, A. \& González, M. Changes in Venezuelan Orinoco belt crude after different biotechnological approaches. J. Petrol. Sci. Eng. 127, 421-432 (2015).

3. Doggett, T. \& Rascoe, A. Global energy demand seen up 44 percent by 2030 , Reuters, 27 Mayıs http://www.reuters.com/article/GCAGreenBusiness/ idUSN2719528620090527?pageNumber=1\&virtualBrandChannel=10531 (2009).

4. Diya'uddeen, B. H., Daud, W. M. A. W. \& Aziz, A. A. Treatment technologies for petroleum refinery effluents. Process Saf. Environ. 89, 95-105 (2011).

5. Kaushik, C. P., Sangwan, P. \& Haritash, A. K. Association of polycyclic aromatic hydrocarbons (PAHs) with different sizes of atmospheric particulate in Hisar city and its health aspects. Polycycl. Aromat. Comp. 32, 626-642 (2012).

6. Effendi, H., Munawaroh, A. \& Ayu, I. P. Crude oil spilled water treatment with Vetiveria zizanioides in floating wetland. Egypt. J. Aquat. Res 43, 185-193 (2017).

7. Abdel-Shafy, H. I. \& Mansour, M. S. A review on polycyclic aromatic hydrocarbons: source, environmental impact, effect on human health and remediation. Egypt. J. Petrol. 25, 107-123 (2016).

8. Archibald, A. T. Biogeochemistry: wake-up call for isoprene emissions. Nat. Geosci. 4, 659-660 (2011).

9. Dave, B. P., Ghevariya, C. M., Bhatt, J. K., Dudhagara, D. R. \& Rajpara, R. K. Enhanced biodegradation of total polycyclic aromatic hydrocarbons (TPAHs) by marine halotolerant Achromobacter xylosoxidans using Triton X-100 and $\beta$ cyclodextrin-a microcosm approach. Mar. Pollut. Bull. 79, 123-129 (2014).

10. Incardona, J. P. et al. Aryl hydrocarbon receptor-independent toxicity of weathered crude oil during fish development. Environ. Health Perspect. 113, 1755-1762 (2005).

11. Sturve, J., Hasselberg, L., Fälth, H., Celander, M. \& Förlin, L. Effects of North Sea oil and alkylphenols on biomarker responses in juvenile Atlantic cod (Gadus morhua). Aquat. Toxicol. 78, 73-78 (2006).

12. Haritash, A. \& Kaushik, C. Seasonal and spatial occurrence and distribution of respirable particulate-bound atmospheric polycyclic aromatic hydrocarbons in Hisar City (India) and their potential health-risks. Asian J. Water Environ. Pollut. 8, 73-80 (2011).

13. Kaushik, C. \& Haritash, A. Polycyclic aromatic hydrocarbons (PAHs) and environmental health. Our Earth 3, 1-7 (2006).

14. Ishak, S., Malakahmad, A. \& Isa, M. H. Refinery wastewater biological treatment. J. Sci. Ind. Res. 71, 251-256 (2012).

15. Kulkarni, S. J. Biological treatment of petroleum wastewater: A review on research and studies. Int. J. Petrol. Petrochem. Eng. 2, 17-21 (2016).

16. Yu, L., Han, M. \& He, F. A review of treating oily wastewater. Arab. J. Chem. 10, 1913-1922 (2017).

17. Haritash, A., Verma, M. \& Shan, V. Degradation of acid Yellow 36 (AY36) dye using Fenton's Process. Int. J. Environ. Sci. 6, 1061-1067 (2016).

18. ljaz, A., Iqbal, Z. \& Afzal, M. Remediation of sewage and industrial effluent using bacterially assisted floating treatment wetlands vegetated with Typha domingensis. Water Sci. Technol. 74, 2192-2201 (2016).

19. Chen, Z. et al. Hydroponic root mats for wastewater treatment. Environ. Sci. Pollut. Res. 23, 15911-15928 (2016).

20. Haritash, A. K., Dutta, S. \& Sharma, A. Phosphate uptake and translocation in a tropical Canna-based constructed wetland. Ecol. Process. 6, 12 (2017).

21. Li, X. \& Guo, R. Comparison of nitrogen removal in floating treatment wetlands constructed with Phragmites australis and Acorus calamus in a cold temperate zone. Water Air Soil Pollut. 228, 132-139 (2017).

22. Ijaz, A., Shabir, G., Khan, Q. M. \& Afzal, M. Enhanced remediation of sewage effluent by endophyte-assisted floating treatment wetlands. Ecol. Eng. 84, 58-66 (2015).

23. Ashraf, S., Afzal, M., Rahman, K., Naveed, M. \& Zahir, Z. A. Plant-endophyte synergism in constructed wetlands enhances the remediation of tannery effluent. Water Sci. Technol. 77, 1262-1270 (2018).

24. Brix, H. Functions of macrophytes in constructed wetlands. Water Sci. Technol. 29, 71-78 (1994).

25. Hallmann, C., Schwark, L. \& Grice, K. Community dynamics of anaerobic bacteria in deep petroleum reservoirs. Nat. Geosci. 1, 588-591 (2008).

26. Weyens, N. et al. J. Exploiting plant-microbe partnerships to improve biomass production and remediation. Trends Biotechnol. 27, 591-598 (2009).

27. Afzal, M., Khan, Q. M. \& Sessitsch, A. Endophytic bacteria: prospects and applications for the phytoremediation of organic pollutants. Chemosphere 117, 232-242 (2014).

28. Khan, S., Afzal, M., Iqbal, S., Mirza, M. S. \& Khan, Q. M. Inoculum pretreatment affects bacterial survival, activity and catabolic gene expression during phytoremediation of diesel contaminated soil. Chemosphere 91, 663-668 (2013). 
29. National Environmental Quality Standards, Government of Pakistan, Islamabad. https://www.elaw.org/system/files/RevisedNEQS.pdf (1999).

30. Afzal, M. et al. Endophytic Burkholderia sp. strain PsJN improves plant growth and phytoremediation of soil irrigated with textile effluent. Clean Soil Air Water 42, 1304-1310 (2014).

31. Haritash, A. K., Sharma, A. \& Bahel, K. The potential of Canna lily for wastewater treatment under Indian conditions. Int. J. Phytorem. 17, 999-1004 (2015).

32. Vymazal, J. The use constructed wetlands with horizontal sub-surface flow for various types of wastewater. Ecol. Eng. 35, 1-17 (2009).

33. Vymazal, J. Constructed wetlands for treatment of industrial waste waters. Ecol. Eng. 73, 724-751 (2014).

34. Rehman, K., Imran, A., Amin, I. \& Afzal, M. Inoculation with bacteria in floating treatment wetlands positively modulates the phytoremediation of oil field wastewater. J. Hazard. Mater. 349, 242-251 (2018).

35. Bezbaruah, A. N. \& Zhang, T. C. pH, redox, and oxygen microprofiles in rhizosphere of bulrush (Scirpus validus) in a constructed wetland treating municipal wastewater. Biotechnol. Bioengin. 88, 60-70 (2004).

36. lamchaturapatr, J., Yi, S. W. \& Rhee, J. S. Nutrient removals by 21 aquatic plants for vertical free surface-flow (VFS) constructed wetland. Ecol. Eng. 29, 287-293 (2007).

37. Lynch, J., Fox, L. J., Owen, J. S. Jr. \& Sample, D. J. Evaluation of commercial floating treatment wetland technologies for nutrient remediation of stormwater. Ecol. Eng. 75, 61-69 (2015).

38. Pilon-Smits, E. Phytoremediation. Annu. Rev. Plant Biol. 56, 15-39 (2005)

39. Sessitsch, A. et al. The role of plant-associated bacteria in the mobilization and phytoextraction of trace elements in contaminated soils. Soil Biol. Biochem. 60, 182-194 (2013)

40. Hansen, A. T., Dolph, C. L., Foufoula-Georgiou, E. \& Finlay, J. C. Contribution of wetlands to nitrate removal at the watershed scale. Nat. Geosci. 11, 127-132 (2018).

41. Idris, R., Trifonova, R., Puschenreiter, M., Wenzel, W. W. \& Sessitsch, A. Bacterial communities associated with flowering plants of the Ni hyperaccumulator Thlaspi goesingense. Appl. Environ. Microbiol. 70, 2667-2677 (2004).

42. Becerra-Castro, C. et al. Endophytic and rhizoplane bacteria associated with Cytisus striatus growing on hexachloro cyclohexane-contaminated soil: isolation and characterization. Plant Soil 340, 413-433 (2011).

43. Ghosh, P., Rathinasabapathi, B. \& Ma, L. Q. Arsenic-resistant bacteria solubilized arsenic in the growth media and increased growth of arsenic hyperaccumulator Pteris vittata L. Bioresour. Technol. 102, 8756-8761 (2011).

44. Amir, H. \& Pineau, R. Release of $\mathrm{Ni}$ and Co by microbial activity in New Caledonian ultramafic soils. Can. J. Microbiol. 49, 288-293 (2003).

45. Hussain, Z. et al. Integrated perspectives on the use of bacterial endophytes in horizontal flow constructed wetlands for the treatment of liquid textile effluent: phytoremediation advances in the field. J. Environ. Manag. 224, 387-395 (2018).

46. Khan, M. U. et al. Cr-resistant rhizo- and endophytic bacteria associated with Prosopis juliflora and their potential as phytoremediation enhancing agents in metal-degraded soils. Front. Plant Sci. 5, 755 (2015).

47. Shehzadi, M. et al. Enhanced degradation of textile effluent in constructed wetland system using Typha domingensis and textile effluent-degrading endophytic bacteria. Water Res. 58, 152-159 (2014).

48. Hussain, Z. et al. Treatment of the textile industry effluent in a pilot-scale vertical flow constructed wetland system augmented with bacterial endophytes. Sci. Total Environ. 645, 966-973 (2018).

49. Brix, H., Sorrell, B. K. \& Lorenzen, B. Are Phragmites-dominated wetlands a net source or net sink of greenhouse gases? Aquat. Bot. 69, 313-324 (2001)

50. Brix, H. et al. Large-scale management of common reed, Phragmites australis, for paper production: a case study from the Liaohe Delta, China. Ecol. Eng. 73, 760-769 (2014)

51. Fatima, K., Imran, A., Amin, I., Khan, Q. M. \& Afzal, M. Plant species affect colonization patterns and metabolic activity of associated endophytes during phytoremediation of crude oil-contaminated soil. Environ. Sci. Pollut. Res. 23, 6188-6196 (2016).

52. Stout, L. M. \& Nüsslein, K. Biochemical potential of aquatic plant-microbe interactions. Curr. Opin. Biotechnol. 21, 339-345 (2010).

53. Srivastava, J. K. et al. Plant-microbe interaction in aquatic system and their role in the management of water quality. Appl. Water Sci. 7, 1079-1090 (2016).

54. Calheiros, C. S. C., Pereira, S. I. A., Brix, H., Rangel, A. O. S. S. \& Castro, P. M. L. Assessment of culturable bacterial endophytic communities colonizing Canna flaccida inhabiting a wastewater treatment constructed wetland. Ecol. Eng. 98, 418-426 (2017).
55. Fatima, K., Imran, A., Amin, I., Khan, Q. M. \& Afzal, M. Successful phytoremediation of crude-oil contaminated soil at an oil exploration and production company by plants-bacterial synergism. Int. J. Phytorem. 20, 675-681 (2018).

56. Compant, S., Clément, C. \& Sessitsch, A. Plant growth-promoting bacteria in the rhizo- and endosphere of plants: their role, colonization, mechanisms involved and prospects for utilization. Soil Biol. Biochem. 42, 669-678 (2010).

57. Mitter, B. et al. Comparative genome analysis of Burkholderia phytofirmans PsJN reveals a wide spectrum of endophytic lifestyles based on interaction strategies with host plants. Front. Plant Sci. 4, 120 (2013).

58. Siciliano, S. D., Germida, J. J., Banks, K. \& Greer, C. W. Changes in microbial community composition and function during a polyaromatic hydrocarbon phytoremediation field trial. Appl. Environ. Microbiol. 69, 483-489 (2002).

59. Saleem, H., Rehman, K., Arslan, M. \& Afzal, M. Enhanced degradation of phenol in floating treatment wetlands by plant-bacterial synergism. Int. J. Phytorem. 20, 692-698 (2018).

60. Yousaf, S. et al. Hydrocarbon degradation and plant colonization by selected bacterial strains isolated from Italian ryegrass and birds foot trefoil. J. Appl. Microbiol. 109, 1389-1401 (2010).

61. Fatima, K., Afzal, M., Imran, A. \& Khan, Q. M. Bacterial rhizosphere and endosphere populations associated with grasses and trees to be used for phytoremediation of crude oil contaminated soil. Bull. Environ. Contam. Toxicol. 94, 314-320 (2015).

62. Tahseen, R. et al. Rhamnolipids and nutrients boost remediation of crude oilcontaminated soil by enhancing bacterial colonization and metabolic activities. Int. Biodeterior. Biodegrad. 115, 192-198 (2016).

63. Afzal, M., Khan, S., Iqbal, S., Mirza, M. S. \& Khan, Q. M. Inoculation method affects colonization and activity of Burkholderia phytofirmans PsJN during phytoremediation of diesel-contaminated soil. Int. Biodeterior. Biodegrad. 85, 331-336 (2013).

64. Eaton, A. D., Clesceri, L. S., Rice, E. W. \& Greenberg, A. E. Standard Methods for the Examination of Water and Wastewater (Centennial Edition, Washington, 2005).

65. Michaud, L., LoGiudice, A., Saitta, M., DeDomenico, M. \& Bruni, V. The biodegradation efficiency on diesel oil by two psychrotrophic Antarctic marine bacteria during a two-month-long experiment. Mar. Pollut. Bull. 49, 405-409 (2004).

66. Afzal, M., Yousaf, S., Reichenauer, T. G. \& Sessitsch, A. The inoculation method affects colonization and performance of bacterial inoculant strains in the phytoremediation of soil contaminated with diesel oil. Int. J. Phytorem. 14, 35-47 (2012).

67. Afzal, M., Yousaf, S., Reichenauer, T. G., Kuffner, M. \& Sessitsch, A. Soil type affects plant colonization, activity and catabolic gene expression of inoculated bacterial strains during phytoremediation of diesel. J. Hazard. Mater. 186, 1568-1575 (2011).

68. Yousaf, S., Afzal, M., Reichenauer, T. G., Brady, C. L. \& Sessitsch, A. Hydrocarbon degradation, plant colonization and gene expression of alkane degradation genes by endophytic Enterobacter ludwigii strains. Environ. Pollut. 159, 2675-2683 (2011).

69. Peng, S., Zhou, Q., Cai, Z. \& Zhang, Z. Phytoremediation of petroleum contaminated soils by Mirabilis jalapa L. in a greenhouse plot experiment. J. Hazard. Mater. 168, 1490-1496 (2009).

70. Al-Baldawi, I. A., Abdullah, S. R. S., Suja, F., Anuar, N. \& Idris, M. Phytotoxicity test of Scirpus grossus on diesel-contaminated water using a subsurface flow system. Ecol. Eng. 54, 49-56 (2013).

71. Afzal, M., Shabir, G., Hussain, I. \& Khalid, Z. M. Paper and board mill effluent treatment with the combined biological-coagulation-filtration pilot scale reactor. Bioresour. Technol. 99, 7383-7387 (2008).

Open Access This article is licensed under a Creative Commons Attribution 4.0 International License, which permits use, sharing, adaptation, distribution and reproduction in any medium or format, as long as you give appropriate credit to the original author(s) and the source, provide a link to the Creative Commons license, and indicate if changes were made. The images or other third party material in this article are included in the article's Creative Commons license, unless indicated otherwise in a credit line to the material. If material is not included in the article's Creative Commons license and your intended use is not permitted by statutory regulation or exceeds the permitted use, you will need to obtain permission directly from the copyright holder. To view a copy of this license, visit http://creativecommons. org/licenses/by/4.0/.

(c) The Author(s) 2019 